\title{
A Study on Elite Mango Genotypes in Odisha-An Avenue for Crop Improvement
}

\author{
Suvalaxmi Palei, Basant Kumar Das, Kailash Chandra Mohapatra and Dilip Kumar Dash \\ Department of Fruit Science and Horticulture Technology, Orissa University of Agriculture and Technology, Bhubaneswar, \\ Odisha-751003, India
}

\begin{abstract}
A study was carried out among the local mango types in Odisha to explore their genetic variations for further utilization in crop improvement, as the genetic diversity serves as a way for the population to adopt the changing edapho-climatic condition. From 17 districts of Odisha, a total of 548 seedling trees were observed, but only 30 mango elites were selected on the basis of organoleptic test for taste, flavor and aroma. Different physico-chemical characters, like fruit size, shape, colour, flavour, aroma and other characteristics, varied widely among these genotypes. The results of the study with respect to 30 numbers of local mango genotypes revealed that the maximum individual fruit weight (510 g) and pulp percentage (78.4\%) was recorded in Kali. The other desirable traits of the minimum stone percentage (5.9\%) and the maximum pulp to stone ratio (12.5:1) was observed in Nakei. The minimum peel percentage (10.0\%) and the maximum total soluble solid (TSS) percentage (26\%) was recorded in the fruits of Mitha and Lori, respectively. Attractive fruit skin colour was observed in the genotypes Nakei and Belua (yellowish), followed by Sundari (yellow with orange tinge) and Kadalia (greenish yellow). But in case of check mango cultivars Amrapali and Mallika, desirable traits, like the maximum TSS, pulp percentage, pulp to stone ratio and the minimum stone percentage was exhibited by Amrapali, whereas Mallika had the maximum fruit weight. The shape and skin colour are neither attractive nor preferred in both the commercial cultivars, so above cited eye catchy traits can be incorporated into these two superior mango genotypes from the local genotypes to meet the market demand and export potential.
\end{abstract}

Key words: Elite genotypes, mango, crop improvement.

\section{Introduction}

Though crowned by the name of king of fruits, mango (Mangifera indica L.) till now does not possess a role model variety having good fruit quality with desirable characters, like dwarf growth habit, regularity in bearing, attractive fruit colour, good fruit size, disease and pest resistance, due to complexity in breeding behavior, like incompatibility among the varieties, polyembryony and complex inheritance pattern [1]. Mango is one of the ancient fruits of India, and its cultivation appears to have begun 4,000 years ago [2]. It was originated as alloploid. Its home was suggested as Eastern India, and later extended from Assam to Burma or possibly further in Malay region

Corresponding author: Suvalaxmi Palei, Ph.D. student, research fields: in vitro plant regeneration through tissue culture, fruit breeding (conventional and biotechnological approach) and plant growth regulator in fruit physiology.
[3]. Based on recent findings [4], the centre of origin and diversity of genus Mangifera is now firmly established in Southeast Asia. The genus Mangifera consists of 41 species and all the edible cultivars of mango belong to single species $M$. indica L.. A large variability exists in mango germplasm throughout the country [5]. Being an ancestral home for mango germplasm, India is having more than thousand verities, which are widely distributed in different agro climatic zones [6]. India is the largest mango producing country, with an annual production of 16.2 million ton and occupies an area of 2.5 million ha, which accounts for $65 \%$ of total world production [7]. There are bright prospects of building up a flourishing trade for the export of this fruit. Although mangoes are exported to nearly 20 countries, whereas its products are exported to over 40 countries [8] and still there are many doors pending to be opened to flourish trading for export of 
this fruit. In the state of Odisha, mango occupies 14.23 thousand ha with production of 103.73 thousand metric tonne and productivity is 7.3 metric tonne/ha [7]. Besides increasing the production and productivity status, it is the alarming time for the production of quality fruits, so as to attract importers and local consumers and improve the mango export scenario of the country as a whole. India is considered as the world's richest germplasm centre. Available genotypes vary widely with respect to fruit shape, size, fruit skin colour, time of maturity, stone size, pulp quantity and quality, total soluble solids (TSS), yield and regularity in bearing $[1,6,9]$. For improvement of fruit quality, the desirable traits of the different local genotypes are needed to be intensively surveyed, collected, evaluated and exploited to develop the suitable cultivars through hybridization programme [10]. In India, improvement of mango through breeding was initiated as early as 1911 [9]. However, systematic hybridization work was started during 1940s. As a result, four hybrids, namely, Swarna Jehangir (Chinnswarnarekha $\times$ Jehangir), Neelogoa (Neelum $\times$ Mulgoa), Neeluddin (Neelum $\times$ Himayuddin) and Neelshan (Neelum $\times$ Baneshan) were released at Fruit Research Station, Kodur, Karnataka, India [6]. Mango varieties Neelphonso (Neelum $\times$ Alphonso), Neeleshan (Neelum $\times$ Baneshan) and Neeleshwari (Neelum $\times$ Dashehari) were developed at Gujarat Agricultural University [6]. New hybrids Mallika (Neelum $\times$ Dashehari) and Amarpali (Dashehari $\times$ Neelum) were developed at Indian Agricultural Research Institute (IARI), New Delhi, India. Ratna (Neelum $\times$ Alphonso) and Sindhu (Ratna $\times$ Alphonso), which were referred as seedless, were developed at Konkan Krishi Vidyapeet, Dapoli, Maharashtra, India [6]. At Punjab Agricultural University (PAU), Hyderabad, AuRumani (Rumani $\times$ Mulgoa) and Manjeera (Rumani $\times$ Neelum) hybrids were developed after systematic hybridization work [6]. At Indian Institute of Horticultural Reasearch (IIHR), Bangalore, Arka Aruna (Banganappalli $\times$ Alphonso),
Arka Puneet (Alphonso $\times$ Banganappalli) and Arka Anmol (Alphonso $\times$ Janardhan Pasand) were developed and these varieties possess the regular bearing nature [6]. But due to adaptation of hybrid genotype, the genetic base is eroding at very fast rate. Keeping these in view, some important mango growing regions of the state of Odisha were surveyed to collect and explore the fruits of the different local elite mango genotypes as well as the popular mango cultivars which are in demand in Odisha.

\section{Methodology}

\subsection{Collection of Mango}

The study was undertaken by selecting the mango elites from the locally observed plants from 17 different districts of Odisha (Table 1). A total of 30 varieties were selected for physiochemical study from the 548 observed seedling mango trees. Ripe fruits were collected on the basis of local appreciation for different characters on the basis of organoleptic test for taste, aroma, flavour and colour [11]. The mother

Table 1 District wise data about the observed mango seedling trees.

\begin{tabular}{ll}
\hline District & Number of mango seedling trees selected \\
\hline Sudergarh & 20 \\
Mayurbhanj & 37 \\
Keonjhar & 18 \\
Balasore & 12 \\
Cuttack & 62 \\
Bhadrak & 7 \\
Jagatsinghpur & 2 \\
Nayagarh & 124 \\
Khorda & 15 \\
Phulbani & 4 \\
Rayagada & 26 \\
Sambalpur & 26 \\
Jharsuguda & 10 \\
Bolangir & 22 \\
Deogarh & 34 \\
Dhenkanal & 9 \\
Angul & 36 \\
\hline Total & $464+84^{*}=548$ \\
84 lines have & been identified in different districts, but \\
selection was not made due to lack of desirable characters.
\end{tabular}


plants were tagged for future references and for collection of scion sticks for further multiplication. Ten fruits were randomly selected from each of the 30 mango elites. In this study, Amrapalli and Mallika were used as check, because these are the most promising mango cultivar of India and highly preferred by farmer as well as consumer. These two cultivars are leading in current conditions with most of the desirable traits.

\subsection{Measurement of Physiological Characters}

Seven physiological characters, i.e., fruit weight, fruit length, pulp\%, stone\%, peel\%, pulp:stone ratio, TSS, with skin colour were recorded after harvesting. After harvest, length was recorded by taking a representative sample of 10 fruits in each treatment and fruits were collected from three tress of the same genotype. The fresh weight of fruit, pulp, stone and peel were recorded by using electronic balance. Then the pulp to stone ratio was calculated. Ten fruits of mango were randomly taken as sample from each tree. Average fruit weight was calculated in g/fruit. Fruit length was recorded with the help of vernier caliper and their average was calculated in $\mathrm{cm}$. The colour of fruit was assessed on the basis of Royal colour chart. These observations were taken at the optimum maturity of the fruit. Pulp weight was calculated by subtracting the peel and stone weight from total weight of fruit. Pulp content was expressed in percentage. To calculate the pulp to stone ratio, the stone weight was subtracted from the total weight of fruit and the value obtained was divided by stone weight. The amount of TSS was found out as degree Brix by using Erma refractometer as well as digital refractometer.

\subsection{Statistical Analysis}

The data recorded for various parameters were subjected to statistical analysis by using randomized block design [12]. Analysis of variance was conducted for various characters by using computer programme
CPCS1 [12].

\section{Results and Discussion}

The physico-chemical analysis of these 30 mango elites revealed that wide range of variability was present with respect to fruit size, shape, colour, flavour, aroma and other fruit characters. The range of variation amongst these mango elites and local check was noted in Table 2, for average fruit weight, fruit length, pulp percentage, stone weight, peel percentage, pulp:stone ratio and TSS. The highest fruit weight was recorded in the mango elite Kali (510 g), followed by Badamohan (470 g), and the minimum fruit weight was recorded from Gurudi (90 g). The highest pulp percentage (78.4\%) with sweet taste was also recorded in the elite Kali, but the lowest pulp percentage was found in Lori (34.1\%). Elite Chandrama had the highest fruit length $(13.5 \mathrm{~cm})$, followed by Langalkantia $(13.0 \mathrm{~cm})$ and Kanchasuadi and Belua (12 $\mathrm{cm})$, whereas the minimum fruit length was observed in panihandi $(5.0 \mathrm{~cm})$. Stone percentage was the lowest $(5.9 \%)$ in Nakei, but the undesirable character of the highest stone percentage (33.3\%) was recorded in Rasunia having the smell of garlic. The lowest peel percentage $(10 \%)$ was observed in the elite Mitha and the highest in Lori (42.1\%) with sweet taste. Pulp: stone ratio was the lowest in Rasunia (1.5) and the highest in Nakei (12.5). The highest TSS (26\%) was recorded in Lori, followed by Dahipatali (25\%), but the minimum TSS was recorded in Rasunia (11\%). It was identified that five elite trees, viz., Chandrama, Gajagachha, Lambri, Patali and Langalkantia, possess the juiciness characteristics [13]. The popular genotype Naka and Chandan also possess high TSS [14]. This character can be incorporated in breeding programme, because TSS was highly hereditary (99.83\%) and selection of parents with this character may be useful for selection of progenies with high TSS content [11]. Similar observations were reported by Desmukh and Budrukkar [15] and Parida and Ray [16]. 
Table 2 Fruit characteristics of some promising mango elites of Odisha with the checks.

\begin{tabular}{|c|c|c|c|c|c|c|c|c|c|}
\hline No. & Name of the elite & Location & $\begin{array}{l}\text { Fruit } \\
\text { weight (g) }\end{array}$ & $\begin{array}{l}\text { Fruit length } \\
(\mathrm{cm})\end{array}$ & Pulp (\%) & Stone (\%) & Peel (\%) & Pulp:stone ratio & TSS (\%) \\
\hline 1 & Chandrama & Athagarh & 280 & 13.5 & 53.6 & 21.4 & 25.0 & 2.5 & 20 \\
\hline 2 & Langalkantia & Khurda & 350 & 13.0 & 68.7 & 14.2 & 17.1 & 4.8 & 16 \\
\hline 3 & Kalia & Sundargarh & 200 & 8.0 & 60.0 & 15.0 & 25.0 & 4.0 & 19 \\
\hline 4 & Badamohan & Rayagada & 470 & 11.2 & 74.5 & 10.6 & 14.9 & 7.0 & 17 \\
\hline 5 & Nakei & Phulbani & 340 & 11.5 & 73.5 & 5.9 & 20.6 & 12.5 & 16 \\
\hline 6 & Lori & Sambalpur & 210 & 9.0 & 34.1 & 23.8 & 42.1 & 1.6 & 26 \\
\hline 7 & Dahipatali & Bolangir & 190 & 10.5 & 50.0 & 26.4 & 23.6 & 1.9 & 25 \\
\hline 8 & Mitha & Bolangir & 200 & 5.0 & 77.5 & 12.5 & 10.0 & 6.2 & 15 \\
\hline 9 & Kanchasuadia & Baripada & 350 & 12.0 & 68.6 & 8.6 & 22.8 & 8.0 & 18 \\
\hline 10 & Suakhai & Anugul & 200 & 7.5 & 57.5 & 12.5 & 30.0 & 4.6 & 19 \\
\hline 11 & Dahibasa & Dhenkanal & 410 & 11.2 & 70.7 & 9.8 & 19.5 & 7.2 & 14 \\
\hline 12 & Panihandi & Sambalpur & 110 & 5.0 & 72.7 & 13.6 & 13.7 & 5.3 & 20 \\
\hline 13 & Gajagachha & Bhadrak & 170 & 7.0 & 70.6 & 11.7 & 17.7 & 6.0 & 20 \\
\hline 14 & Gotumi & Athamallick & 190 & 8.3 & 68.4 & 15.8 & 15.8 & 4.3 & 16 \\
\hline 15 & Patali & Sundargarh & 150 & 7.5 & 66.7 & 13.3 & 20.0 & 5.0 & 25 \\
\hline 16 & Naki & Bolangir & 210 & 7.5 & 71.4 & 11.9 & 16.7 & 6.0 & 21 \\
\hline 17 & Guamala & Dhenkanal & 240 & 8.0 & 48.0 & 12.0 & 40.0 & 4.0 & 21 \\
\hline 18 & Kadalia & Sambalpur & 190 & 9.0 & 63.2 & 15.8 & 21.0 & 4.0 & 21 \\
\hline 19 & Belua & Deogarh & 270 & 12.0 & 70.4 & 11.1 & 18.5 & 6.3 & 16 \\
\hline 20 & Rasunia & Keonjhar & 150 & 8.0 & 50.0 & 33.3 & 16.7 & 1.5 & 11 \\
\hline 21 & Sundari & Khurda & 150 & 9.0 & 66.7 & 13.3 & 20.0 & 5.0 & 18 \\
\hline 22 & Gurudi & Jagatsinghpur & 90 & 5.5 & 50.0 & 22.2 & 27.8 & 2.2 & 22 \\
\hline 23 & Rajbhog & Cuttack & 300 & 8.0 & 70.0 & 13.3 & 16.7 & 5.2 & 16 \\
\hline 24 & Krushnaballav & Athgarh & 400 & 11.0 & 65.0 & 17.5 & 17.5 & 3.7 & 21 \\
\hline 25 & Plant No.41 & Nayagarh & 303 & 8.7 & 65.6 & 17.8 & 16.6 & 3.7 & 20 \\
\hline 26 & Plant No. 103B/10 & Nayagarh & 300 & 8.7 & 58.5 & 17.5 & 24.0 & 3.3 & 15 \\
\hline 27 & Plant No.126 & Nayagarh & 217 & 10.5 & 65.0 & 17.8 & 17.2 & 3.6 & 21 \\
\hline 28 & Mohanbansi & Balasore & 380 & 10.9 & 72.2 & 10.6 & 17.2 & 6.8 & 18 \\
\hline 29 & Kaliagaja & Talcher & 150 & 7.3 & 66.7 & 20.0 & 13.3 & 3.3 & 18 \\
\hline 30 & Kali & Cuttack & 510 & 11.0 & 78.4 & 9.8 & 11.8 & 8.0 & 19 \\
\hline Mean & & & 256 & 9.17 & 64.27 & 15.30 & 20.42 & 4.91 & 18.80 \\
\hline Critic & difference (CD) & & 7.43 & 0.99 & 2.87 & 1.32 & 1.97 & 0.68 & 1.23 \\
\hline Range & & & $90-510$ & $5.0-13.5$ & 78.4-34.1 & 26.4-5.9 & $42.1-10.0$ & $12.5-1.5$ & $25-11$ \\
\hline \multicolumn{10}{|c|}{ Checks } \\
\hline 1 & Amrapali & & 221.3 & 11.10 & 87.12 & 11.80 & 17.0 & $4.4: 1$ & 23.5 \\
\hline 2 & Mallika & & 236.0 & 13.09 & 86.03 & 18.76 & 10.6 & 7.4:1 & 22.7 \\
\hline
\end{tabular}

Attractive fruit skin colour was observed in the genotypes Nakei and Belua (yellowish), Sundari (yellow with orange tinge) and Kadalia (greenish yellow). But in case of check mango cultivars, the desirable traits, like the maximum TSS (23.5\%), pulp percentage (87.12\%), and the minimum stone percentage (11.8\%) were obtained in Amrapali, whereas Mallika had the maximum fruit weight (236 g) and high pulp to stone ratio (7.4:1). But the shape and skin colour is neither attractive nor preferred in both the commercial cultivars. So above cited eye catchy traits can be incorporated into the two superior mango genotypes from the local genotypes to meet the market demand and export potential. The yellowish skin colour of Sudari and Nakei is desirable, which can be transferred to these two check mango by hybridization 
programme, as these are highly compatible with both Amrapalli and Mallika as pollinizer (Sundari), resulting in $38 \%$ and $43 \%$ more fruit set and increase in fruit size compared to the open pollinated one [14]. Mallika has the higher percentage of stone, which is also undesirable, while the elite Nakei showed a reduction in stone percentage (only 5.9\%) and therefore, it is a preferable quality to increase marketability.

\section{Conclusions}

Diversity or heterogeneity is the main character desired for breeding either natural or manmade. It is required to have vast genetic pool to get new combinations of desired nature and developing new hybrids. From the aforesaid discussion, it was summarized that the two local checks (Amrapali and Mallika) are not attractive in appearance due to greenish skin colour, whereas the yellow with orange tinge in shoulder is the preferred one. The local elite Sundari and Nakei possess the yellowish skin colour, which can be transferred to these two mango check by hybridization programme. Mallika has the higher percentage of stone, which is also undesirable, while elite Nakei showed only $5.9 \%$ stone. So there is an urgent need for the breeder to develop an ideal mango cultivar by exploiting the genetic potential and utilizing the allelic combination of the germplasm through breeding programme for good fruit quality with desirable characters, like dwarf growth habit, regularity in bearing, attractive fruit colour, good fruit size, disease and pest resistance, etc.. To go for such strategies, a comprehensive knowledge of the physiology of the reproductive parts, their breeding behaviour and cytological information and yield potential of the local mango elites have to be studied.

\section{References}

[1] Singh, R. N. 1990. Mango. New Delhi: Indian Council of Agricultural Research, 134.

[2] Condole, A. 1984. Origin of Cultivated Plants. London: Vegal Paul Trench and Co., 1-67.

[3] Popenoe, F. W. 1920. "The Mango in Southern California." J. Eco. Bot. 1: 153-200.

[4] Mukherjee, S. K. 1997. "The Mango: Its Botany, Cultivation, Uses and Future Improvement, Especially as Observed in India.” Econ. Bot. 7 (2): 130-62.

[5] Gupta, P. N., Rai, M., Bawa, R. S., and Lal, B. 1996. “Genetic Diversity of Mango in Western Uttar Pradesh.” Indian J. Plant. Genetic Res. 11 (1): 54-6.

[6] Yadav, I. S., and Ranjan, S. 1993. "Genetic Resources of Mangifera." In Advances in Horticulture, edited by Chadha, K. L., and Pareek, O. P. Vol. 1. New Delhi: Malhotra Publishing House, 77-82.

[7] Gandhi, C. P. 2015. "Indian Horticulture Database 2014." National Horticulture Board, Ministry of Agriculture, Government of India. Accessed February, 2015. http://nhb.gov.in/area-pro/NHB_Database_2015.pdf.

[8] Negi, S. S., Rajan, S., and Kumar, R. 2000. "Developing New Mango Varieties through Hybridization.” Acta Hort. 506: 159-70.

[9] Iyer, C. P. A. 1991. "Recent Advances in Varietal Improvement in Mango.” Acta Hortic. 291: 109-32.

[10] Burns, W., and Prayag, S. H. 1921. The Book of Mango. Bombay: Bombay Department of Agriculture.

[11] Das, B. K., Ray, D. P., and Acharya, G. C. 2007. "Genetic Variability in Mango Germplasm of Orissa." Indian J. Hort. 64 (1): 29-33.

[12] Singh, S. 2003. "Evaluation of Mango Cultivars for Their Flowering, Fruiting and Fruit Quality Attributes.” Prog. Hort. 34 (2): 240-3.

[13] Ray, D. P., Das, B. K., Dash, R. C., and Parida, G. N. 1992. "Survey and Selection of Local Seedling Mangoes of Orissa.” Orissa J. Hort. 20: 43-51.

[14] Dash, R. C., and Hota, B. N. 1977. "Some Indigenous Mango Varieties of Orissa.” Orissa J. Hort. 5: 35-52.

[15] Desmukh, P. A., and Budrukkar, N. D. 1985. "Promising Mango Selections from Himayatbag.” Acta Hort. 231: 97-9.

[16] Parida, G. N., and Ray, D. P. 1989. "Classification and Selection of Some Elite Mangoes in Orissa.” Acta Hort. 231: 89-92. 